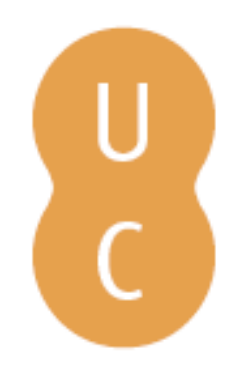

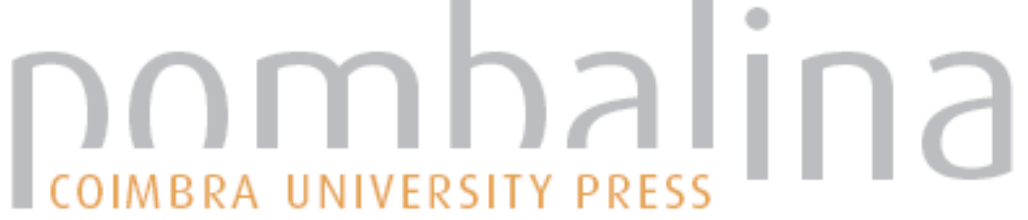

\section{O banquete romano e os pueri delicati: uma convivialidade privada}
Autor(es):
Santos, Alexandra Coelho dos
Publicado por: Imprensa da Universidade de Coimbra
URL persistente:
URI:http://hdl.handle.net/10316.2/45243
DOI:
DOI:https://doi.org/10.14195/978-989-26-1720-6_3

Accessed : $\quad$ 26-Apr-2023 02:10:39

A navegação consulta e descarregamento dos títulos inseridos nas Bibliotecas Digitais UC Digitalis, UC Pombalina e UC Impactum, pressupõem a aceitação plena e sem reservas dos Termos e Condições de Uso destas Bibliotecas Digitais, disponíveis em https://digitalis.uc.pt/pt-pt/termos.

Conforme exposto nos referidos Termos e Condições de Uso, o descarregamento de títulos de acesso restrito requer uma licença válida de autorização devendo o utilizador aceder ao(s) documento(s) a partir de um endereço de IP da instituição detentora da supramencionada licença.

Ao utilizador é apenas permitido o descarregamento para uso pessoal, pelo que o emprego do(s) título(s) descarregado(s) para outro fim, designadamente comercial, carece de autorização do respetivo autor ou editor da obra.

Na medida em que todas as obras da UC Digitalis se encontram protegidas pelo Código do Direito de Autor e Direitos Conexos e demais legislação aplicável, toda a cópia, parcial ou total, deste documento, nos casos em que é legalmente admitida, deverá conter ou fazer-se acompanhar por este aviso.

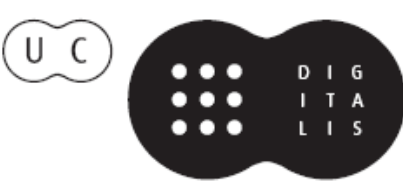


Carmen Soares

\section{Cilene da Silva Gomes Ribeiro}

\section{(coords.)}

MESAS

\section{ALIMENTAÇÃ O, SAÚDE \& CULTURA}

\section{IU LUO-BRASILEIRAS}

\section{VOLUME II}

IMPRENSA DA UNIVERSIDADE DE COIMBRA

COIMBRA UNIVERSITY PRESS

PUCPRESS 


\title{
O BANQUETE ROMANO E OS PUERI DELICATI: UMA CONVIVIALIDADE PRIVADA
}

\author{
(The roman banquet and the pueri delicati: \\ private conviviality)
}

\author{
Alexandra Coelho dos Santos \\ Universidade de Coimbra \\ Faculdade de Letras \\ Centro de Estudos Clássicos e Humanísticos \\ da Universidade de Coimbra \\ ALEXASANTOS54@HOTMAIL.COM
}

Resumo: Os banquetes na Antiga Roma surgem como uma manifestação cultural e social, onde valores e demonstrações de poder eram acompanhados da extravagância de comida e de bebida, de emoções e impulsos carnais. Assim, a par da "sedução gastronómica", o banquete romano, local privilegiado de prazer, goza com a presença e companhia dos denominados pueri delicati, os escravos favoritos que se tornam presenças eróticas que provocam o desejo dos seus senhores nestes momentos de comensal deleite romano. $\mathrm{O}$ erotismo latente neste tipo de manifestação cultural à mesa é acrescido dessa presença que encanta os olhos a par da satisfação de uma das necessidades primárias do corpo, a ingestão de alimentos, ainda que de forma excessiva, mas que fazem parte de uma histórica manifestação romana. Pretende este trabalho dar testemunho do prazer e do lazer que inundavam o banquete, da presença erótica que estes meninos traziam ao convívio social do banquete romano, conduzindo a uma satisfação psíquica e, por vezes, física, já que muitas vezes era consumado o ato sexual entre o puer delicatus e o seu senhor. Apresentaremos algumas referências textuais de autores de cariz clássico que abordam a questão destes tipos de rituais e hábitos sociais.

PALAVRAS-CHAVE: banquete romano, puer delicatus.

ABSTRACT: Banquets in ancient Rome arose as a cultural and social event where values and displays of power were accompanied by the extravagance of food and drink, emotions and carnal impulses. Thus, along with the "culinary seduction", the Roman feast, privileged place of pleasure, enjoyed the presence and company of so-called pueri delicati, favorite slaves who became the erotic presence that trigger the desire of their masters in these moments of Roman delight dinner. The latent eroticism in this kind of cultural event to the table is increased by this presence that delights the eye along with the primary needs of the body and food intake, even excessively, 
being however part of a historic Roman manifestation. With this work we want to bear witness of pleasure and leisure that flooded the banquet with erotic presence brought by these boys to roman social life, leading to mental and sometimes physical satisfaction, as the sexual act between puer delicatus and his master was often consummated. We present some textual references of classic authors who address the issue of these types of rituals and social habits.

KEYWORDS: roman banquet, puer delicatus.

A história de Roma surge através de sucessivas conquistas levadas a cabo pela necessidade constante de uma afirmação por parte do povo romano, que ao longo de séculos alargou e consolidou o território, exercendo a sua influência na Europa, Ásia e África.

É certo que a I Guerra Púnica no séc. III a.C. marcou um novo patamar na expansão romana e na mudança de mentalidades. Desde o termo desta guerra, Roma vê-se arrastada a nível cultural para a receção do impacto da cultura helénica ${ }^{1}$.

Costuma considerar-se que a cultura romana não é mais do que um produto do helenismo. Não se pode negar que a afirmação de Roma se dá num mundo em que o helenismo é pano de fundo. Todavia, também este, tendo sobre ele ascendências orientais muito claras, influenciou e partilhou cultura com o mundo ocidental onde implantou as suas colónias. Tanto gregos como romanos partilharam não só os quadros ideológicos bebidos numa herança cultural indo-europeia comum, como também num substrato mediterrânico. É, portanto, natural que certos aspetos do helenismo tenham "colorido a cultura romana de uma forma mais notória que o inverso" 2

Desde as origens de Roma que a influência grega foi feita de forma direta e indireta, sobretudo devido à presença de estrangeiros no seu seio. Como refere Oliveira ${ }^{3}$ em sentido lato, deve entender-se "helenização da cultura romana como um movimento geral de trocas culturais entre Roma e o helenismo inseridas numa tendência geral da época, quando o helenismo, como cultura superior, tendia a criar uma espécie de cultura comum, chamada de koine cultural, no Mediterrâneo". Entre o séc. IV-III a.C., os vários confrontos e conquistas, e o contacto direto com a Grécia e com os seus territórios na Ásia, contribuíram para uma "autopromoção de Roma dirigida tanto às cidades gregas do sul de Itália como ao mundo helenístico em geral [...] ostentando

Cary-Scullard 1975: 168-85 apud Oliveira 2015: 246.

Vd. Oliveira 2015: 265.

Oliveira 2015: 267. 
as suas credenciais como amiga das cidades gregas", tornando-se tal num sinal de abertura ao helenismo 5 .

Mas, este fenómeno de helenização não obscureceu a originalidade da cultura romana, pois o grande feito dos romanos foi a capacidade de absorverem e assimilarem outras culturas sem, no entanto, perderem a sua própria identidade.

Assim, a expansão romana fez-se sentir nos mais variados níveis, entre eles o da própria alimentação e o da forma como entendiam o momento de estar à mesa, nomeadamente em relação aos banquetes, ou convivia.

Como refere Strong

[...] O convivium era tão determinante para os romanos quanto o jantar de gala para os vitorianos. Desde o início, o ato de comer em conjunto transformou uma função corporal necessária em algo muito mais significativo, um evento social. Supunha a aceitação de normas sobre o desenrolar da reunião. No mundo da Antiguidade Clássica, esta foi uma das primeiras ações que distinguiu homens civilizados dos semisselvagens. $\mathrm{O}$ convívio, tanto para os gregos como para os romanos, era visto como uma das pedras angulares da civilização, embora ambígua e complexa. A mesa e os convidados que se reuniam em torno dela para partilharem os seus prazeres podiam ser um veículo de agregação e unidade social [...].

A oferta de banquetes tinha já uma longa tradição nas antigas sociedades mediterrânicas, e são inicialmente associadas a atividades militares (nomeadamente as que têm a ver com as vitórias) e a ocasiões religiosas. Assim, os gregos apresentam-se como um dos povos em que este tipo de convívio era marcante na vida social, como testemunham algumas obras gregas, que demonstram a importância destes tipos de eventos, servindo algumas como pano de fundo do decorrer da ação - lembremo-nos da Ilíada e dos seus festins sem fim num ambiente bélico. Já Plutarco dizia: "Não nos sentamos à mesa para comer, mas para comermos juntos”, traduzindo o contexto em que os banquetes ocorriam, desde a celebração da sacralidade ${ }^{7}$ ao convívio social, onde as discussões literárias e filosóficas abraçavam momentos de música e danças de bailarinas.

Entre elas encontramos, como exemplo, O Banquete de Platão, o Banquete dos Sete Sábios e No Banquete de Plutarco, e ainda O Banquete de Xenofonte, onde, as fervorosas discussões sob temáticas culturais eram acompanhadas

\footnotetext{
Dench 1995: 68-69.

Cf. Oliveira 2015: 267-268.

Strong 2004: 14.
}

Apenas para dar um exemplo, encontramos no epílogo d'O Banquete dos Sete Sábios de Plutarco, em 164d, Sólon a propor o encerramento do encontro com libações às Musas, a Poséidon e a Anfritite: "Façamos pois libações às Musas, a Poséidon e a Anfitrite e, se vos parecer bem, vamos dar por terminado o banquete” (trad. Delfim Leão 2008: 123). 
pelo excesso de bebida, levados muitas vezes ao extremo, até às conhecidas orgias. Estes diálogos de Platão e Xenofonte apresentam-se como verdadeiros testemunhos da importância que os banquetes tinham, já que nos oferecem descrições detalhadas dos costumes e das regras a que obedeciam ${ }^{8}$.

É n'O Banquete de Platão que encontramos referência "à atmosfera do symposium, onde a liberdade de expressão e a "verdade" do vinho triunfam

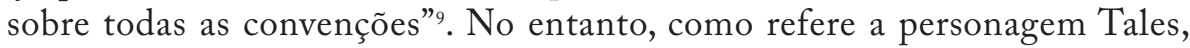
com uma pitada de bom humor, no Banquete dos Sete Sábios, "quem possui discernimento não vai para um banquete levando-se a si mesmo como se fora um vaso para encher, mas antes para conversar a sério e brincar, para ouvir e para falar de acordo com o que ocasião sugerir aos participantes, se a companhia de uns e de outros se revelar agradável" (147 E). Temos, pois, de destacar que as profícuas discussões travadas nestas reuniões elevavam o nível destes eventos, já que acabaram por ser documentados a nível literário ${ }^{10}$.

$\mathrm{Na}$ Grécia, o symposium ocorria depois das refeições, e os convivas, ainda que não tivessem vínculos de parentesco, partilhavam idêntico estilo de vida e formação cultural. Além do consumo do vinho misturado com água, os convidados conversavam sobre diversas temáticas, cantando e recitando. Este momento de sociabilidade era uma importante manifestação de coesão social e de unidade cultural, e era utilizado como critério de diferenciação entre o grego e o bárbaro, levando mesmo os rituais e as regras inerentes à comensalidade a tornarem-se um elemento constitutivo da própria identidade grega ${ }^{11}$.

Tal como os symposia gregos, também os banquetes na Antiga Roma surgem como uma manifestação cultural e social, onde valores e demonstrações de poder são acompanhados da extravagância de comida e de bebida, de emoções e impulsos carnais. Assim, a par da gastronomia, os banquetes romanos apresentavam um outro tipo de deleite, um prazer que passava pela presença dos pueri delicati nestas manifestações de convivium romano, sobre os quais trataremos mais adiante.

Um banquete poderia ter diferentes significados do ponto de vista Romano: o convívio para comer e beber forma um dos mais significativos rituais no mundo romano, e desempenha, por exemplo, um papel essencial nas relações, seja entre os membros das elites e os seus dependentes, seja com os seus potenciais apoiantes, ou com a sua comunidade inteira ${ }^{12}$.

Cf. Azevedo 1991: 11, n. 4.

Azevedo 1991: 16.

10 Na parte central d'O Banquete dos Sete Sábios de Plutarco (155d-164d), o banquete serve de cenário para discussões sobre várias temáticas, desde o amor ao vinho, passando pelos bens materiais até à própria alimentação (cf. Leão 2008: 9).

11 Andrade 2016: 21.

12 Dunbabin 2003: 2. 
As festividades feitas em torno da comida e da bebida eram um importante ritual no mundo Romano. Conhecidas por convivia, os Romanos distinguiam diferentes tipos de encontros à mesa: o epulum (banquetes públicos), cena (jantar, normalmente realizado a meio da tarde) e o comissatio (festim de bebida, música e dança que se realizava noite fora).

Um verdadeiro jantar romano era constituído por três pratos: as entradas (gustatio), o prato principal (mensae prima) e a sobremesa (mensae secunda). Estes tipos de jantares eram verdadeiros espetáculos, não só a nível de comida como na forma como ela era servida. A ementa possuía variados tipos de alimentos, desde o peixe à carne, aos produtos de elevado custo e raros de se encontrar. Nesta altura foram inventados elaborados pratos, chegando-se mesmo a atingir um distinto grau de extravagância, como testemunha o texto de Petrónio, na sua Cena Trimalquionis.

O vinho nos banquetes romanos era servido durante a refeição, uma prática diferente do mundo grego, em que a refeição principal (deipnon) era consagrada à comida e o vinho reservado para o symposium, que a seguia. Um dos componentes do banquete era o entretenimento que envolvia espetáculos de música, acrobatas, bailarinas, lutas entre gladiadores, mimos, ou mesmo espetáculos com animais, como leões. No entanto, a literatura também não era esquecida, e a poesia, as histórias e atuações dramáticas faziam parte do banquete. Além das mulheres que atuavam, os escravos faziam parte do espetáculo, desde os cozinheiros que cantavam enquanto serviam os convidados, ou os belos escravos que deleitavam os olhos de quem participava no jantar ${ }^{13}$.

Neste âmbito, podemos verificar que a cultura romana é decididamente uma cultura visual, como se pode apurar pelos testemunhos que chegaram até nós. $\mathrm{O}$ convivium romano foi retratado em todas as eras da história Romana pela literatura, como uma ocasião para interação social num ambiente de exibição visual dramática. Plutarco enfatiza essas qualidades nas suas Questiones Convivales ${ }^{14}$ escritas no séc. I, e oferece uma fonte rica no que respeita a esta questão neste período do Império. Plutarco caracteriza os jantares aristocráticos como uma "procissão e espetáculo", descrevendo o cenário como "um lugar de teatro ou um palco para visitantes" ${ }^{15}$.

Stephenson ${ }^{16}$ refere que o banquete no Império Tardio, apesar de partilhar muito com os seus antecedentes, revela novidades no que toca à representação visual: excêntricas formas no que concerne às divisões, espalhafatosos e coloridos interiores, mobílias e decorações altamente teatrais inspiradas nas representações públicas, e especialmente novas disposições para a realização

\footnotetext{
13 Vd. Raff 2011.

14 Cf. Plutarco, Quaestiones Convivalis 7.

15 Stephenson 2016: 61.

16 Stephenson 2016: 60.
} 
de espetáculos durante as refeições. Todas estas mudanças significativas, entre os séculos III e IV, no que tange à mobília, decoração ou entretenimento, eram sem dúvida um verdadeiro espetáculo visual. A tudo isto junta-se a nova forma de disposição dos participantes, que muito tem a ver com a realidade política, onde a gradação do estatuto dos mesmos está muito mais definida. Estas mudanças estão largamente relacionadas com a competição do estatuto dentro da época do Império Tardio, "when a ritually saturated commensality joined art and action to differentiate the players" ${ }^{17}$.

Mas, tal como acontecia nos primeiros tempos, também nesta época os banquetes serviam para o anfitrião mostrar a sua generosidade perante um círculo de amigos. Não devemos esquecer igualmente os banquetes oferecidos pelos imperadores que se tornaram espetáculos oficias e cerimoniais de estado ${ }^{18}$. Plutarco e Plínio (o Jovem) apresentam aquilo que pode ser a visão idealizada da finalidade e da prática do jantar durante o Principado. Segundo Plutarco, uma refeição formal representa a oportunidade de fazer e reafirmar importantes conexões sociais, políticas e económicas, com o consumo de comida como segundo propósito ${ }^{19}$.

Não há dúvida que os banquetes gregos e romanos desmedidos (ainda que difiram em alguns pontos) existiram e ficaram para sempre na memória. Mas é importante salientar que eram feitos ocasionalmente pelas elites romanas, apesar de alguns imperadores os realizarem com maior frequência, e entre esses excessos, o gastronómico foi o de maior alcance, e encontram eco nas fontes literárias, como em tratados de gastronomia, em obras de carácter filosófico ou satírico, ou nos testemunhos das próprias escavações arqueológicas.

A arte culinária fosse ela para o dia-a-dia ou para o deleite nos banquetes, apresentou-se como portadora de uma grande importância para os antigos romanos, como nos testemunham alguns tratados como o De re coquinaria de Apicius e o Banquete dos Eruditos de Ateneu. A alimentação encontra ecos igualmente nas obras de Columela, Varrão, Catão, e na História Natural de Plínio ${ }^{20}$. Podemos também encontrar no XIII livro de Epigramas de Marcial um rol de variedades gastronómicas, com referência às iguarias que provinham do Mediterrâneo, da África ou da Europa, assim como em Juvenal e Marcial ${ }^{21}$.

Inicialmente os romanos tinham uma alimentação essencialmente vegetariana. A abertura a novas técnicas de exploração agrárias alargou o conhecimento e facilitou a introdução de novas plantas e animais. Mas não só esta introdução de novos elementos contribuiu para a diversificação da

\footnotetext{
Stephenson 2016: 60 .

Cf. Stephenson 2016: 60.

Cf. Plutarco, Quaestiones Convivalis 4. 660.

Rodrigues 2014: 72.

Cf. Carcopino 1964: 296-298.
} 
alimentação romana: o contacto com a culinária grega e oriental foi importantíssimo. Condimentos e iguarias exóticos importados, desenvolvimento da panificação, da pecuária e piscicultura, assim como a importação e aluguer de cozinheiros, destinados a satisfazer os gostos dos romanos por banquetes privados, os convivia e comissationes acompanharam essa modificação no plano alimentar e social dos romanos ${ }^{22}$.

Os banquetes são igualmente referenciados e servem de pano de fundo de algumas cenas em obras de carácter satírico, como nas obras de Plauto, ou nas obras de Titínio, Afrânio ou Atta. Num registo mais sério, podemos encontrar esta referência nas Catilinárias de Cícero, nomeadamente na Segunda Catilinária, quando alerta acerca dos perigos a que os romanos poderiam estar expostos durante um banquete:

Esses que, estendidos pelos leitos dos banquetes, abraçados a mulheres sem pudor, amolecidos pelo vinho, empanturrados pela comida, coroados de grinaldas, besuntados de perfumes, enfraquecidos pela devassidão, vomitam nas suas palavras a morte dos homens de bem e os incêndios da cidade (V.10).

As escavações arqueológicas, como em Pompeia e Herculano, surgem também como testemunhos vivos do tipo e da forma de alimentação romanas, fossem elas refeições frugais, fossem banquetes desmedidos. As pinturas nas paredes das casas de Pompeia mostram frequentemente cenas de banquetes onde os convivas se apresentam em perfeita luxúria e relaxamento, desfrutando do jantar que lhes é oferecido. É interessante atentar que alguns momentos parecem inspirados nos modelos helenísticos, como o facto de algumas mulheres surgirem retratadas segundo o modelo grego das heterai, enquanto outras como matronas respeitáveis.

Após o período de arte de Pompeia (depois de 79 a.C.) temos representações de banquetes em contexto doméstico; algumas representações situam-se no campo de festividades romanas associadas a comemorações funerárias. $\mathrm{O}$ banquete era igualmente importante e central nos rituais familiares, como nascimentos e casamentos, além das mortes ${ }^{23}$.

Não poderemos, no entanto, deixar de mencionar o Satyricon de Petrónio, com a sua famosa Cena Trimalchionis, que se apresenta como o retrato da ostentação e sobejamento de um novo-rico liberto, que convida ao prazer na

22 Para desenvolvimento deste tópico e dos produtos utilizados na alimentação romana, vide por ex., Grainger, S. (2006), Cooking Apicius: Roman recipes for today, Prospect Books, Devon, e Oliveira 2015: 274-275.

${ }_{23}$ Como exemplo, temos o caso do sarcófago de P. Caecilius Vallinus, um oficial militar do séc. III, que surge em contexto familiar, reclinado, enquanto os seus escravos the servem a comida e o entretêm com instrumentos musicais, e duas crianças brincam com um cão. 
sua totalidade, pois segundo as suas próprias palavras "Já que sabemos que iremos morrer, porque não aproveitamos a vida?" ${ }^{24}$. Surge, pois, um ignorante novo-rico que fora escravo a tentar imitar o real da alta sociedade.

Segundo Pasquier (1988: 323-332 apud Almeida 2001: 68), e como já foi anteriormente mencionado, o banquete era a expressão da comunidade hierarquizada, visível no lugar que se ocupava na mesa, nos alimentos que faziam parte da ementa e que se consumiam, assim como do número de pratos que se serviam.

Assim, seguindo regras, como a utilização de um vestuário próprio constituído pelo synthesis e pelo pallium, a posição dos convidados na hierarquia do banquete era extremamente importante, já que eram dispostos segundo a proximidade com o seu anfitrião. Assim, denota-se as relações de poder no próprio banquete, não só pela posição dos convidados mas também pela forma como os alimentos eram distribuídos. Como referem Flandrin e Montanari ${ }^{25}$, se a oferta fosse feita de cima para baixo deveria entender-se como uma "condescendência generosa e de preeminência social", enquanto de baixo para cima denotaria uma veneração e sujeição face ao dono da casa. No fundo, o convivium permitia que um senhor exibisse as suas conquistas e realizações aos seus pares dentro da sua casa e no seio familiar. Estes aspetos são bem documentados nas Saturnais de Macróbio, escritas no início do séc. V d.C.

Assim, consumada em posição reclinada, marcando uma posição de usufruto dos prazeres do otium, os banquetes romanos, mais do que momentos de desfrute de uma opulenta gastronomia, eram importantes no seio social, já que se transformaram em manifestações de poder e de valores, e reforçavam as hierarquias no seio da sociedade romana. Os próprios romanos consideravam a posição reclinada indispensável para o seu conforto físico, mas traduzia-se também como uma marca de elegância e de distinção social.

Mas, no aparato do banquete romano, além do senhor da casa e dos convidados, a existência de escravos apresentava-se como um elemento importante no "desfile" deste convivium.

No respeitante ao banquete, os comensais eram atendidos por escravos que desempenhavam diferentes funções: assim, encontramos o nomenclator, que acomodava os convidados, seguindo ordem de etiqueta e anunciava os pratos à medida que chegavam à sala; os scissores, que cortavam os alimentos, ou o cellarius, que estava encarregue dos vinhos e que orientava os escravos jovens mais belos que enchiam os copos dos convidados, os denominados glaber.

A escravatura em Roma fazia parte da identidade cultural deste grande Império. Ao contrário do que alguns pensam, muitos eram aqueles que faziam

\footnotetext{
24 Satyricon, LXXII, 5-7.

25 Flandrin, Montanari 1998: 109.
} 
parte do séquito de alguns senhores, como nos testemunha Tácito; Ateneu afirma mesmo que, no início do Império, uma grande quantidade de escravos era uma demonstração de riqueza e estatuto ${ }^{26}$.

Uma vez que o estatuto foi associado à riqueza, era muitas vezes demonstrado e assumido de diferentes maneiras: desde o avarento de Apuleio, que vivia numa pequena casa devido ao facto de querer esconder a sua riqueza, possuindo apenas um escravo (Met.1.21), a Séneca, que refere que, na sua altura, viver numa boa casa e possuir numerosos e belos escravos eram símbolos associados à riqueza e status (Ep. 41.7). Um século mais tarde, Apuleio, ao falar de Crates apontou que, segundo este, a demonstração de riqueza tinha a ver com uma grande comitiva de escravos e com um vestíbulo luxuosamente decorado (Flor. 22). O certo é que o número de escravos da casa romana era sinónimo de riqueza; chegava-se ao ponto de considerar que o mesmo escravo não podia desempenhar diferentes tarefas. Por isso, assistiu-se ao aumento do seu número dentro das casas romanas, distinguindo-os através das suas vestes ou penteados ${ }^{27}$.

Assim, encontrava-se nos banquetes a presença de jovens escravos que desempenhavam as mais diversas funções e, entre eles, os pueri delicati, ou deliciae domini, delicium ou deliciolum, os escravos que faziam as delícias dos seus senhores, durante e depois do banquete. Ovídio escreve: "A comida e o vinho servem alegremente para tornar mais afáveis os jogos de sedução".

No âmbito do contexto que aqui apresentamos, ao contrário dos Gregos, em que a pederastia exigia a igualdade social dos amantes, ou seja, era necessário que o jovem fosse de condição livre para que o amor se desenrolasse com reciprocidade e comunhão intelectual, os romanos, por sua vez, preferiam comprar o prazer $^{28}$. Mais do que isso, a aristocracia romana, influenciada pelas modas e costumes gregos, acabou por adaptá-los mas sem a sua substância intelectual e hedonista; sentiam-se obrigados a ter em suas casas jovens belos ${ }^{29}$, rapazes imberbes, de traços delicados, que faziam mais do que os trabalhos domésticos ou o serviço às mesas nos grandes banquetes.

A questão é que a relação de pederastia "cidadão/futuro cidadão", culturalmente valorizada na Grécia, acabou por ocupar um grande lugar no imaginário erótico dos romanos, quando se trata, por exemplo, dos jovens embelezados e perfumados, que eram denominados por nomes gregos ${ }^{30}$. A relação sexual entre homens em Roma, diferentemente do que se passava na Grécia, considerava-se na medida em que fosse uma relação entre um homem

\footnotetext{
272e; 273c apud Thomas Wiedeman, 73-74.

Cf. Garnsey, Saller 2015: 144.

Conde Ortega 2001: 166.

Conde Ortega 2001: 166.

Boehringer 2008: 207.
} 
livre e um escravo, e simplesmente num âmbito de prazer; desta forma, o desejo sexual por um corpo masculino é aceite, mas somente se a satisfação é encontrada num escravo ou num liberto.

As histórias retratadas nas várias obras revelam que a sociedade romana demonstrava uma certa preocupação social de um homem se submeter a outro sexualmente; a ameaça de penetrar outro homem, na literatura latina e aparentemente na realidade romana, era usada como um símbolo de superioridade viril e de poder $^{31}$.

A poesia erótica reforça a ideia de que a pederastia era aceite na sociedade, e o louvor a rapazes bonitos era um lugar-comum nos epigramas. $\mathrm{O}$ certo é que, além da literatura, a presença de imagens de pederastia nos graffitis sugere que havia um orgulho nela, e que não se restringia apenas aos elevados níveis da sociedade; apesar de não se poder negar a influência dos epigramas helenísticos nos romanos, a influência grega e asiática na pederastia romana deve ser vista como uma argumentação, e não como uma base. É interessante atentar no facto de que alguns homens ricos e com altas posições deploram a pederastia, sobretudo no que respeita aos seus filhos ${ }^{32}$.

A relação sexual com jovens escravos era não só normal como aceitável, enquanto com rapazes livres era considerada deplorável e mesmo ilegal, sobretudo para a reputação e orgulho do rapaz no futuro. Séneca, o Velho, refere que "A impudicitia num homem livre é um crime, num escravo é um dever, num liberto é um serviço" (Contr. 4, pref. 10). Aliado a este fato, deve-se salientar que existe uma sacralidade face ao corpo do vir, do homem livre, e toda a tentativa de violar a sua integridade física constituem uma ação de infâmia ao qual é proibido o acesso na masculinidade adulta ${ }^{33}$. A questão da masculinidade romana passa pela imposição de que nenhum corpo masculino de homem livre dever ser penetrado sexualmente por outro homem: o homem deve sempre assumir uma posição ativa, nunca uma atitude passiva face ao outro: ser um vir (homem) implica que o seu corpo nunca seja violado, pois se o for há um atentado claro à sua virtus.

O ideal de beleza do puer retratado nos epigramas eróticos surge não como algo secundário, mas com tanta importância como a exaltação da beleza feminina. A poesia acerca de rapazes é uma poesia extremamente idealizada, tal como acontece com as mulheres; são evitadas descrições de detalhes físicos, e a emoção expressada é altamente convencional ${ }^{34}$.

Nos poemas onde são retratados os pueri, estes são imaginados como intemporais; na pior das hipóteses surgem ameaçados por bigodes e pelos

\footnotetext{
31 Vd. Richlin 1992: 221.

32 Cf. Richlin 1992: 222-224.

33 Cf. Torregarai Pagola 2010: 13-14.

34 Richlin 1992: 34.
} 
no corpo, isto porque nunca são imaginados como adultos mas sim como eternas crianças, rapazes representados como objetos de desejo, de amor. No cômputo geral, os pueri são apresentados como escravos vendidos nos leilões, ou surgem nas festas despejando o vinho aos convidados do seu dono.

O filósofo Philo de Alexandria ${ }^{35}$, conhecedor das extravagâncias da domus imperial, já que viveu em Alexandria nos primeiros anos de soberania romana, na sua De vita contemplativa (50-52), fornece-nos uma das melhores descrições da presença de escravos-rapazes em contexto de convivialidade, e comenta a beleza dos rapazes que transportam água e fazem o vazamento de vinho. As suas faces estão pintadas com cosméticos, os seus longos cabelos estão habilmente aparados e entrelaçados, e as suas túnicas são fabricadas com finos tecidos. Sabemos, não só por Philo, mas também por outros autores como Petrónio, Marcial, Suetónio, Séneca e Apuleio, que estes jovens escravos que servem à mesa são valorizados pelos seus longos cabelos, tanto que são referidos como: capillati, comati, criniti, crispuli e calamistrati ${ }^{36}$.

Suetónio, por exemplo, referindo-se aos hábitos pessoais de Galba, descreve o tratamento que o imperador dava aos seus escravos de mesa quando comia e a sua predileção especial por "muito difíceis exoleti" ${ }^{77}$ ('jovens devassos'). Lampridus descreve os excessos de Commodus dentro do seu palácio imperial, incluindo a referência aos púberes exoleti ${ }^{38}$.

Os textos literários permitem-nos saber que nos convivia era usual que o dominus romano tivesse relações sexuais com jovens escravos rapazes, incluindo aqueles que serviam à mesa, e Séneca denuncia os "tratamentos vergonhosos" (contumelia) que esperavam os jovens escravos após os jantares privados, expressando mesmo a sua reserva moral acerca do tratamento dos escravos nas casas dos grandes senhores: "Passo pelos tristes rebanhos de rapazes que esperam, no final do banquete, outros ultrajes no quarto" ${ }^{39}$.

35 Este judeu helenizado, que tentou uma interpretação do Antigo Testamento à luz das categorias elaboradas pela filosofia grega e a alegoria, confronta, neste contexto em que nos debruçamos, os escravos dos banquetes pagãos com a ausência dos mesmos nos Terapeutas, porque estes consideravam que a escravatura era contrária à natureza, ou seja, que todos somos livres.

36 Capillati: Petron. 27; Mart. 2.57.5; comati: Mart. 12.70.9; 12.97.4; Suet. Cal. 35; criniti: Sen. Ep. 119.14; Mart.12.49.1; crispuli: Sen. Ep.95.24; calamistrati: Isid. Orig. 10.57; Apul. Met. 2.19. Cf. Keegan 2007: 8.

37 Suet. Galba 22: "cibi plurimi traditur, quem tempore hiberno etiam ante lucem capere consuerat, inter cenam vero usque eo abundantis, ut congestas super manus reliquias circum ferri iuberet spargique ad pedes stantibus. Libidinis in mares pronior et eos non nisi praeduros exoletosque".

38 Neste âmbito, enquanto 300 adolescentes participavam em atos sexuais durante o jantar e o banho, o escritor especifica que eles não são escravos, mas foram retirados à força de famílias plebeias e aristocráticas (cf. Keegan 2007: 23).

39 Séneca, Cartas a Lucílio, XV. 
No que respeita ao escravo servidor de vinho durante um banquete, escreve o poeta-filósofo:

Outro escravo escanciador de vinho, vestido à maneira de mulher, luta com os anos; não lhe está permitido a juventude, é empurrado violentamente contra ela; e alcançada a idade militar, tem o corpo liso, barbeado todo o pelo, completamente depilado; passa a noite acordado, dividindo o seu tempo entre a bebedeira do seu senhor e a sua luxúria; no quarto tem de ser um homem, na festa um rapaz ${ }^{40}$.

Deparamo-nos com a importância que estes jovens escravos tinham no seio das famílias aristocráticas, formando, sem dúvida, parte do luxo da domus. Estes jovens, comprados por valores altíssimos, provenientes de várias zonas de África, como Egito, Etiópia ou Síria, não só serviam para assistir às mesas, mas também para satisfazer sexualmente os seus amos; nos banquetes lavavam as mãos e os pés dos convidados, distribuíam os pratos e o vinho, ao mesmo tempo que dançavam e cantavam ${ }^{41}$.

Acontecia mesmo que os senhores, depois de comerem, secavam as mãos nos seus longos cabelos devidamente cuidados. Suetónio relata como Augusto procurava crianças, de bonito e agradável aspeto, e de origem exótica (Aug. 83, 2).

Como refere Puccini-Delbey, "O ambiente do banquete e a sua sociabilidade permitem o eclodir de um erotismo masculino ideal, precioso, requintado e aristocrático, cuja figura central é o escravo favorito (puer delicatus) [...] a face iluminada do seu avesso sórdido, o cinaedus ${ }^{42}$ ". No entanto, Juvenal é um dos autores que critica este comportamento depravado nas festas.

Estes jovens educados, muitas vezes, em escolas especiais surgem como um elemento de luxo e de requinte nos banquetes romanos a partir do séc. II a.C., e, apresentando-se como simbolicamente gregos, são transformados em criados gregos, cujo modelo é Ganimedes, o efebo enamorado de Zeus, que levado por uma águia, serve como criado no banquete dos deuses. Para Puccini-Delbey, "o erotismo masculino ideal encontra-se então na infância, na beleza, no luxo, no prazer e na cultura grega" ${ }^{43}$.

A presença destes jovens escravos no banquete, vestidos à maneira grega, proporcionando primeiramente um prazer aos olhos e só depois uma satisfação sexual aos seus senhores, introduz um mote de erotismo à festa. Durante o

40 Sen. Ep. 47.7: "alius vini minister in muliebrem modu mornatus cum aetate luctatur: non potest effugere pueritiam, retrahitur, iamque militari habitu glaberret ritis pilis aut penitus evulsis tota nocte pervigilat, quam inter ebrietatem domini ac libidinem dividitet in cubiculo vir, in convívio puer est".

41 Cf. Conde Ortega 2001: 166-167.

42 O termo cinaedus designa originariamente um dançarino que meneia as nádegas de maneira sugestiva. Cf. F. Dupont e T. Eloi, L'Érotisme masculin dans la Rome antique.

43 Puccini-Delbey 2010: 121. 
banquete, apenas os olhos e a boca do pueri são erotizadas. Muitas vezes, o beijo que senhor e escravo dão traduz-se numa anulação dos estatutos sociais; e, como refere Thierry Éloi ${ }^{44}$, o beijo no banquete opõe-se à felação - estes apresentam-se como "duas práticas do corpo amoroso tipicamente romanas e que transgridem aquilo a que chamamos diferenciação sexual" 45 .

Os seus corpos tratados, depilados, perfumados, de pele suave e branca, muitas vezes pela utilização de cosméticos, atraíam os senhores de uma forma altamente sexual. Apenas o surgimento da primeira barba pode despojá-los deste trabalho e torná-los não desejáveis aos olhos dos seus senhores.

Segundo Florence Dupont e Thierry Éloi, é legítimo dar o nome de Ganimedes aos pueri delicati, esses escravos indispensáveis na cultura dos banquetes, como nos invoca este poema de Marcial ${ }^{46}$ :

Cada vez que me fixo no teu Hilo quando serve o vinho, censuras-me, ó Afro, com um olhar mais que sombrio.

Que crime, pergunto, que crime existe em olhar um criado que é lindo? Olhamos o sol, as estrelas, os templos, os deuses.

Hei-de afastar o olhar como se as bebidas fossem oferecidos pela Górgona e procurasse os meus olhos e a minha cara?

Feroz era Hércules, mas permitia olhar a Hilas; a Mercúrio foi-lhe consentido brincar com Ganimedes.

Se não queres que os convidados admirem os teus delicados escravos, convida, ó Afro, os Fíneos e os Édipos ${ }^{47}$.

Mas, enquanto na sociedade grega este Ganimedes é um jovem livre, que vive uma fase na sua passagem para a vida adulta, na sociedade romana é um escravo forçado a permanecer artificialmente confinado à sua juventude ${ }^{48}$.

44 Éloi 2001: 259 apud Puccini-Delbey 2010: 124.

45 Tomando como referência a questão do beijo na cultura grega, n'O Banquete de Xenofonte (Pinheiro 2008: 53-54), Sócrates refere "não há nada de mais perigoso para atiçar o amor, porque um beijo é insaciável e leva a esperanças voluptuosas. [E o facto, de entre todos os nossos comportamentos, só a união dos lábios ter a mesma designação do amor das almas, faz com que o beijo tenha um importância muito maior. / e por isso digo que aquele que quiser ser casto não deve beijar rapazinhos" (4.25-26).

46 Vd. tb. Os Epigramas I, 6; V, 55; IX, 16, 36; XI, 22, 26, 43, 104.

47 "Dantem vina tuum quotiens aspeximus Hyllum, / Lumine nos, Afer, turbidiore notas./ Quod, rogo, quod scelus est, mollem spectare ministrum? / Aspicimus solem, sidera, templa, deos. / Avertam vultus, tam quam mihi pocula Gorgon / Porrigat atque oculos oraque nos trapetat? / Truxerat Alcides, et Hylan spectare licebat; / Ludere Mercurio cum Ganymede licet. /Si non vis teneros spectet conviva ministros, / Phineas invites, Afer, et Oedipodas" (Epigrammata, IX,25). As referências a Fíneo e Édipo devem-se à sua condição de cegueira: Fineo, adivinho da Trácia deixou os seus filhos do seu primeiro casamento cegos, tendo Zeus o castigado, deixando-o cego também. Édipo, o herói tebano, vazou os seus olhos ao descobrir que tinha matado o seu pai e casado com a sua mãe.

48 Gély 2008: 14-15. 
Os pueri delicati foram idealizados na poesia: nas elegias eróticas de Tibulo, o seu delicatus Marathus veste roupas luxuosas e caras; a beleza do delicatus é medida pelos padrões de Apolónio, especialmente no que se refere ao "seu longo cabelo", que supostamente deve ser ondulado e perfumado.

Também Horácio tinha o seu menino favorito e apesar de mencionar outros nas suas obras, Ligurinus era o principal. $\mathrm{Na}$ sua poesia expôs sem dramas a bissexualidade dos homens romanos, e também a sua, como em algumas das suas Sátiras (1.2.116-118,1.4.27 e 2.3.325). Apenas para dar um exemplo, na Sátira 1.2.116-118, o poeta escreve sobre o desejo que despertam os escravos jovens, tanto as meninas como os meninos: "quando te incham as virilhas/ se tivesses uma escrava ou um escravo em quem descarregar/ o teu ataque, preferias rebentar de ardor amoroso? Eu não./ Amo a Vénus acessível e fácil”"49.

Catulo, ao mesmo tempo que dedica toda uma paixão por Lésbia, parece igualmente alimentar amor por um jovem, Juvêncio, e dedica-lhe também poemas como puer delicatus ${ }^{50}$. A ele oferece-lhe estas belas palavras:

Esses teus olhos de mel, Juvêncio,

Quem me dera beijá-los sem parar,

Sem parar os beijaria trezentas mil vezes,

E me pareceria que nunca ficaria satisfeito,

nem que a densidade das espigas secas

fosse mais cerrada que os nossos beijos ${ }^{51}$.

Nas Silvae de Estácio encontramos igualmente esta admiração pelos jovens rapazes, sobretudo por Earino, a criança oferecida como "escravo sexual" ao imperador Domiciano:

Não vi nem criei nada mais doce, nada, o confesso, no mundo inteiro.

Perante ti cederia a criança de Latmos, Endimion, e de Sangário, Atis, e aquele que foi consumido pelo seu vão reflexo na fonte e por um estéril amor, Narciso. A ti, haveria preferido a cerúlea Náiade e te haveria arrastado com maior força puxando o cântaro, Hilas. Tu, criança, superas a

49 "tument tibi cum inguina, num, si / ancilla aut verna est praesto puer, impetus in quem / continuo fiat, malis tentigine rumpi?/ non ego: manque parabilem amo venerem facilimque". (Bonifaz Nuño 1993: 11).

50 Salientamos que, no caso de Catulo, o seu Juventus era um ingenuus, um rapaz romano nascido livre; o Marathus de Tibulo parece ser uma criação da sua imaginação poética; em Horácio, sim vemos, por um lado, nas Sátiras, uma atração por escravos rapazes que não podiam resistir aos avanços do seu senhor, e por outro, nas Odes, uma requintada celebração aos belíssimos pueri delicati (Verstraete 2012: 165).

51 "Mellitos oculos tuos, Iuuenti,/ si quis me sinat usque basiare,/ usque ad milia basiem trecenta,/ nec numquam videar satur futurus,/ non si densium aridis aristis/ sit nostrae seges osculationes" (Cat., XLVIII). 
todos. Unicamente é mais formoso que tu aquele a quem vais ser entregue.

Ao longo do poema fala-se da vida de Earino até ao momento da sua libertação como "escravo sexual", da relação matrimonial entre amo e escravo, simbolizada pelo corte de cabelo, assim como da sua castração, feita para que não perdesse a sua juventude e não lhe surgisse a barba, alterações que fariam com que ele deixasse a sua condição de preferido do seu senhor, celebrando a sua depositio barbae (feita entre os 17 e 18 anos).

Alguns poemas de Marcial, como é o caso de 9.8, em que se refere igualmente ao caso de Domiciano e de Earino, pode ser aproximado da questão da necessidade de revitalizar as leis contra a prostituição de crianças do sexo masculino, mostrando mesmo a distinção a nível literário sobre as diferentes categorias da pederastia. Marcial pede a Domiciano que proteja a criança dos males que se associam às prostitutas, ou seja, Earino não é um prostituto mas um copeiro do imperador. No fundo, a sensibilidade de Marcial adotada na sua poesia permite ao mesmo tempo fantasiar sexualmente a partir de um rapaz, que surge como um objeto de amor, e deplorar o nível sórdido da prostituição ${ }^{52}$.

N o Satyricon de Petrónio, como refere Delfim Leão, "são frequentes as peripécias motivadas pela entrada em cena de belos jovens, que despertam noutras personagens um misto de arrebatamento irrefletido ou mesmo de fúria descontrolada, consoante as circunstâncias que acompanham e motivam o jogo de sedução" ${ }^{53}$.

A entrada em cena de Trimalquião é feita "no meio de escravos de cabelos compridos", que evidenciam a sua riqueza. Mas durante o banquete que ofereceu, há uma clara perversão do erotismo aristocrático que se deveria encontrar nele. Assim, ao mesmo tempo que num ato de certo devaneio despede um grupo de escravos substituindo-o por outros, atira-se e beija um deles que se encontra entre o grupo e lhe desperta atenção (Satyricon, 74,8). A par desta situação, exibia-se com o seu escravo favorito Creso, que estava longe dos padrões de beleza nos quais eram incluídos estes jovens escravos. Creso, o puer delicatus de Trimalquião (o novo rico que também fora o puer delicatus de um senhor e a quem satisfazia os desejos sexuais e da sua mulher) surge em cena no banquete oferecido pelo seu senhor, como "um miúdo todo remeloso" (Satyricon 64.6), um jovem muito pouco desejável!

\footnotetext{
52 Cf. Richlin 1992: 40.

53 Leão 2006: 119.
} 


\section{Considerações finais}

In sum, a história de Roma é perpassada por conquistas que permitiram a expansão e que consequentemente levaram à criação de conceitos políticos, socias e culturais distintos de qualquer outra sociedade. No entanto, não se poderá negar que essas mesmas conquistas contribuíram para trocas que deixaram verdadeiras marcas na herança romana: entre elas, encontra-se a alimentação. $\mathrm{O}$ facto de os romanos considerarem importante a reunião em torno da mesa, apesar de ter bebido alguma influência nos povos com os quais contactaram, traduz-se como verdadeira inovação, tendo em conta sobretudo alguns dos rituais que a ela estavam associados.

Assim, além das opulentas refeições, os pueri delicati surgiram como "elementos" presenciais essenciais no seio das famílias aristocráticas romanas, escravos que acompanhavam os homens da alta sociedade romana nos seus banquetes, já que adoravam nestes jovens aquela beleza e frescura da juventude que começavam a perder. Entre o excesso de vinho e de delícias culinárias, tornaram-se personagens reais de satisfação, primeiramente pela sedução de um olhar, passando para a satisfação carnal propriamente dita, na volúpia dos memoráveis banquetes romanos.

\section{REFERENCIAS}

Almeida, C. A. B. (2001), "O vinho e a pretensa barbárie dos povos galaicos”, DOURO Estudos e Documentos VI.11: 67-81.

Andrade, J. B. (2016), "Corpo e festa na Antiguidade tardia: o convivium nas Saturnais, de Macróbio", Cadernos de Clio 7.1: 13-28.

Azevedo, M. T. S. (1991), Platão, O Banquete, Edições 70, Lisboa.

Boehringer, S. (2008), "Historia de la construcción de la identidade sexual en la Antigüedad griega y romana", Litoral: école lacanienne de psychanalyse 41: 203-219.

Bonifaz Nuño, R. (1993), Horácio, Sátiras, Universidad Nacional Autónoma de México,México.

Carcopino, J. (1964), Daily life in ancient Rome: the people and city at the height of the Empire, Penguin Books, London.

Cary, M., Scullard, H. H. (1975), History of Rome: down to the age of Constantine, Palgrave Macmillan, London.

Conde Ortega, J. F. (2001), "El beso de Safo en el jardín de Venus", Temas y Variaciones de Literatura 17: 163-178.

Dunbabin, K. M. D. (2003), The roman banquet: images of conviviality, Cambridge University Press, Cambridge.

Dench, E. (1995), From Barbarians to new man. Greek, Roman, and Modern Perception of peoples from the Central Apennines, Oxford University Press, Oxford.

Dupont, F., Éloy T. (2001), L'Érotisme masculin dans la Rome antique, Belin, Paris. 
Flandrin, J. L., Montanari, M. (1998), História da Alimentação, Estação Liberdade, São Paulo.

Garnsey, P., Saller, R. (2015), The Roman Empire: economy, society and culture, University of California Press, Oakland.

Gély, V. (2008), Ganymède ou l'echanson: rapt, ravissement et livresse poétique, Presses Universitaires de Paris, Paris.

Grainger, S. (2006), Cooking Apicius: Roman recipes for today, Prospect Books, Devon.

Keegan, P. (2007), "Reading the 'Pages' of the Domus Caesaris: pueri delicati, slave education, and the graffiti of the Palatine paedagogium", The Sixth E. T. Salmon Conference in Roman Studies: Roman Slavery and Roman Material Culture September, McMaster University, Hamilton, Ontario, 28-29.

Leão, D. (2006), "Petrónio e a inconstância dos pueri delicati”, Humanitas 58: 119-131.

Leão, D. F. (2008), Plutarco, O Banquete dos Sete Sábios, Centro de Estudos Clássicos e Humanísticos, Coimbra.

Oliveira, F. (2015), “Consequências da Expansão Romana”, in J. L. Brandão, F. Oliveira (ed.), História de Roma Antiga: das origens à morte de César, v. 1, Imprensa da Universidade de Coimbra, Coimbra, 233-311.

Pasquier, A. (1988), "Introduction au théme du symposium", in Les princes celtes et la Mediterranée, Ed. Rencontres de l'École du Louvre, Paris, 323-332.

Pinheiro, A. E. (2008), Xenofonte. Banquete - Apologia de Sócrates, Centro de Estudos Clássicos e Humanísticos, Coimbra.

Pinho, S. T. (1989), Cícero, As Catilinárias, Edições 70, Lisboa.

Puccini-Delbey, G. (2010), A vida sexual na Roma Antiga, Texto \& Grafia, Lisboa.

Raff, K. (2011), “The Roman Banquet”, in Heilbrunn Timeline of Art History, The Metropolitan Museum of Art, New York, Disponível em: <www.metmuseum. org/toah/hd/banq/hd_banq.htm>.

Richlin, A. (1992), The Garden of Priapus: sexuality and aggression in Roman humor, Oxford University Press, Oxford.

Rodrigues, M. V. M. (2014), "Banquetes romanos: comensalidade, hierarquia e poder na Roma Antiga”, NEARCO - Revista Electrônica de Antiguidade VII.II: 72-79.

Stephenson,J. (2016), “Dining as spectacle in late Roman houses”, Bulletin of the Institute of Classical Studies 59.1: 54-71.

Strong, R. (2004), Banquete: uma história ilustrada da culinária, dos costumes e da fartura à mesa, Jorge Zahar, Rio de Janeiro.

Torregarai Pagola, E. (2010), “Sexo en Roma: del mito a la realidade”, in Jornadas sobre la Antigueadad, Prácticas amorosas en el mundo antíguo 29, 1.

Verstraete, B. C. (2012), "Reassessing Roman Pederasty in Relation to Roman Slavery: The Portrayal of Pueri Delicati in the Love-Poetry of Catullus, Tibullus, and Horace”, Uluslararari Sosyal Araştirmalar Dergisi - The Journal of International Social Research 5.20: 157-177. 
(Página deixada propositadamente em branco) 